\section{Influence of Coat Protein Transgene Copy Number on Resistance in Transgenic Line 63-1 against Papaya Ringspot Virus Isolates}

\author{
Manoel T. Souza, Jr., ${ }^{1}$ Paula F. Tennant, ${ }^{2}$ and Dennis Gonsalves ${ }^{3}$ \\ Department of Plant Pathology, Cornell University, Geneva, NY 14456
}

Additional index words. coat protein, papaya, resistance, transgenic, and virus

\begin{abstract}
Line 63-1 is a 'Sunset'-derived transgenic papaya expressing the coat protein (CP) gene from a mild mutant of a Hawaiian isolate of Papaya ringspot virus (PRSV). Previous work showed that line 63-1 $R_{1}$ plants exhibited a range of resistance to severe PRSV isolates from Hawaii (HA), Jamaica (JA), Thailand (TH), and Brazil (BR). Genetic and molecular data obtained in this study confirm that line 63-1 has two $C P$ transgene insertion sites; segregation analysis shows that the $C P$ and the $n p t I I$ genes are present at both loci. To study the potential effect of gene dosage on resistance, various populations of $R_{1}, R_{2}$, and $R_{3}$ seedlings were challenged by PRSV HA, BR, and TH. A $R_{1}$ population obtained by self-pollination of line 63-1 hermaphrodite $R_{0}$ plant exhibited resistance to all three isolates. The percentage of plants resistant to all three PRSV isolates increased in 63-1-derived populations as a result of recurrent selection. Additional genetic studies demonstrate that the number of resistant plants in a 63-1-derived population is directly correlated with the number of plants with multiple transgene copies. We conclude that transgene dosage plays a major role in affecting the resistance of 63-1 to PRSV isolates from various geographical locations.
\end{abstract}

Fitch et al. (1992) were the first to develop a transgenic tree crop resistant to papaya ringspot virus (PRSV). They obtained a Sunset Soloderived transgenic papaya (Carica papaya L.) line, designated 55-1, that expressed the $\mathrm{CP}$ gene from a mild mutant strain PRSV HA 5-1 (Yeh and Gonsalves, 1984) and was seemingly immune to the severe PRSV HA (Gonsalves and Ishii, 1980) isolate. Field trials conducted in Hawaii confirmed the resistance of this line and subsequent derivatives (Ferreira et al., 2002; Lius, 1994; Lius et al., 1997). In May 1998, the first CP transgenic papaya varieties resistant to PRSV were released commercially in the United States (Gonsalves, 1998; Manshardt, 1998). These varieties, named Rainbow and SunUp, were derived from line 55-1 by conventional breeding methods; SunUp is line 55-1 that is homozygous for the single $\mathrm{CP}$ transgene insertion, while Rainbow is a $\mathrm{F}$ hybrid between SunUp and the yellow-flesh variety Kapoho Solo and is hemizygous for the $\mathrm{CP}$ transgene.

When 55-1-derived plants hemizygous for the CP locus were challenged, Tennant et al. (1994) showed that the spectrum of resistance was narrow and resistance was obtained

\footnotetext{
Received for publication 15 Apr. 2005. Accepted for publication 11 July 2005 .

${ }^{1}$ Corresponding author. Current mailing address: Embrapa Genetic Resources and Biotechnology, Parque Estação Biológica, CP 02372, Final Av. W5 Norte, Brasília, DF 70770-900, Brazil; e-mail msouza@cenargen.embrapa.br.

${ }^{2}$ Current mailing address: Biotechnology Centre, University of West Indies, Mona, Jamaica.

${ }^{3}$ Current address: Pacific Basin Agricultural Research Center, ARS-USDA, 99 Aupuni Street, Suite 204, Hilo, Hawaii 96720.
}

against PRSV HA and other Hawaiian isolates but not against isolates from several different geographical regions around the world. However, SunUp plants were subsequently found resistant to a range of isolates from Hawaii and outside of Hawaii; resistance was confirmed RNA-mediated via post-transcriptional gene silencing (PTGS) and dependent on plant age and gene dosage (Tennant et al., 2001). It was clearly shown that as the number of $\mathrm{CP}$ transgene copies doubled from line 55-1 or Rainbow to SunUp, the spectrum of resistance was improved (Tennant et al., 2001).

Besides line 55-1, another transgenic line designated 63-1, has also shown potential application for the control of PRSV (Tennant et al., 2005). Line 63-1 was derived from the work by Fitch et al. (1992). A percentage of 63-1 $R_{1}$ plants derived from a self-crossed hermaphro- dite $\mathrm{R}_{0}$ plant showed resistance to Hawaiian, Jamaican, Brazilian, and Thailand isolates. This is in contrast to line 55-1 where all transgenic plants showed resistance to Hawaiian isolates but no resistance to isolates from outside of Hawaii, such as Brazil and Thailand (Tennant et al., 2001). Further analysis suggested that line 63-1 has more than one CP gene insertion sites (Tennant et al., 2005). As lines 55-1 and 63-1 have the same genomic background (Sunset Solo cultivar) and were transformed with the same gene construct (Ling et al., 1991; Fitch et al., 1992), a better understanding of the resistance behind line 63-1, in contrast to line 55-1 and its derivatives, should help to further comprehend the PRSV: transgenic papaya resistance system and the development of transgenic papaya plants with a wide spectrum of resistance to this virus. The objective of the present study was to evaluate the effects of transgene copy number in line 63-1 against three isolates that differ in geographic location and CP sequence homology.

\section{Materials and Methods}

Virus isolates. Three isolates of PRSV were used in this study; the severe isolate from Hawaii (PRSVHA) (Gonsalves and Ishii, 1980), the Bahia isolate from Brazil (PRSV BR) (Souza and Gonsalves, 2005), and a Thai isolate (PRSV TH) (Tennant et al., 1994). The isolates were obtained from the PRSV bank of isolates at New York State Agriculture Experimental Station (NYSAES) in Geneva, NY. Virus inoculation and disease resistance assessment were performed according to Souza and Gonsalves (2005).

Plant material. A $\mathrm{R}_{1}$ population was generated under greenhouse conditions at the NYSAES in Geneva, N.Y., by the self-pollination of a hermaphrodite plant (Tennant et al., 2005). The generation of $R_{2}$ and $R_{3}$ populations is summarized in Table 1. Population A was obtained by crossing plant 1268 , a $\mathrm{R}_{1}$ 63-1 plant, with a nontransformed Sunrise Solo plant, and population B was obtained by crossing plant 1268 with another $\mathrm{R}_{1}$ 63-1 plant, designated $76 . R_{2}$ populations $C_{1}$ and $\mathrm{C}_{2}$ were obtained by self-pollination of two distinct $63-1 R_{1}$ plants that were resistant to

Table 1. Characteristics of papaya plants that were used as parental sources and as test populations.

\begin{tabular}{|c|c|}
\hline Source & Characteristics \\
\hline \multicolumn{2}{|l|}{ Parental plants } \\
\hline $\mathrm{R}_{\mathrm{o}} 63-1$ & Hermaphrodite $\mathrm{R}_{\mathrm{o}}$ transgenic line transformed with the $c p$ gene of PRSV HA 5-1 \\
\hline $\mathrm{R}_{1}^{\circ}$ plant 1268 & Female from self-pollinated $\mathrm{R}_{0} 63-1$; resistant to PRSV BR \\
\hline $\mathrm{R}_{1}$ plant 76 & Hermaphrodite from self-pollinated $\mathrm{R}_{0} 63-1$; resistant to PRSV JA \\
\hline $\mathrm{R}_{1}$ plant 17 & Hermaphrodite from self-pollinated $\mathrm{R}_{0}^{0} 63-1$; resistant to PRSV BR \\
\hline $\mathrm{R}_{1}$ plant 07 & Hermaphrodite from self-pollinated $\mathrm{R}_{0}^{0} 63-1$; resistant to PRSV BR \\
\hline $\mathrm{R}_{1}$ plant 88 & Hermaphrodite from self-pollinated $\mathrm{R}_{0} 63-1$; resistant to PRSV TH \\
\hline $\mathrm{R}_{\mathrm{o}}^{46-1}$ & Female Ro transgenic line transformed with the $c p$ gene of PRSV HA 5-1; suscept to PRSV HA \\
\hline Sunrise Solo & Nontransgenic papaya that is susceptible to all strains of PRSV \\
\hline \multicolumn{2}{|c|}{ Populations created from parental lines } \\
\hline $63-1 \mathrm{R}_{1}$ & From self pollinated $\mathrm{R}_{0} 63-1$ \\
\hline $63-1 \mathrm{R}_{2} \mathrm{~A}$ & From cross of $R_{1}$ plant 1268 and Sunrise \\
\hline $63-1 R_{2}^{2} B$ & From cross of $\mathrm{R}_{1}$ plant 1268 and $\mathrm{R} 1$ plant 76 \\
\hline $63-1 \mathrm{R}_{2}^{2} \mathrm{C}_{1}$ & From self pollinated $\mathrm{R}_{1}$ plant 17 \\
\hline $63-1 \mathrm{R}_{2} \mathrm{C}_{2}$ & From self pollinated $R_{1}$ plant 07 \\
\hline $63-1 \mathrm{R}_{2}^{2} \mathrm{D}_{1}^{2}$ & From self pollinated $\mathrm{R}_{1}$ plant 88 \\
\hline $63-1 R_{2}^{2} E^{1}$ & From $R_{2}$ plant from cross of $R_{0} 63-1$ and $R$ 46-1; seedlings were resistant to PRSV HA \\
\hline $63-1 \mathrm{R}_{2}^{2} \mathrm{~F}$ & Population similar in origin as 63-1 E; seedlings were resistant to PRSV HA \\
\hline
\end{tabular}


mechanical inoculation with PRSVBR. The $\mathrm{R}_{2}$ population $D_{1}$ was obtained by self-pollination of a 63-1 $R_{1}$ plant that was resistant to mechanical inoculation with PRSV TH (Table 1). $\mathrm{R}_{2}$ progenies were obtained in the greenhouse at the NYSAES in Geneva. $R_{3}$ progenies, $E$ and F, were kindly provided by Richard Manshardt (University of Hawaii at Manoa, Hawaii). They were generated by initially crossing a 63-1 $\mathrm{R}_{0}$ plant with the 46-1 $\mathrm{R}_{0}$ plant (Fitch et al., 1992). Line 46-1 expresses the neomycin phosphotransferase type II (nptII) gene, but not the $\mathrm{CP}$ or uidA genes. The $\mathrm{R}_{1}$ plants from this cross were then screened for resistance to PRSV in the greenhouse; resistant plants were moved to a field at Waimanalo (Oahu, Hawaii) in 1994, and maintained for 2 years (during which time they did not develop symptoms of PRSV). Self-pollinated or sib-mated $R_{2}$ seeds were then planted in another field at Kapoho (Hawaii, Hawaii) in August 1995. The $R_{2}$ plants segregated in the field for resistance to PRSV. Resistant $\mathrm{R}_{2}$ plants at Kapoho were then self-pollinated to produce $\mathrm{R}_{3}$ populations, among them populations $E$ and F. Seeds of populations $\mathrm{A}, \mathrm{B}, \mathrm{C}_{1}, \mathrm{C}_{2}, \mathrm{D}_{1}, \mathrm{E}$, and $\mathrm{F}$ were used in this study.

Polymerase chain reaction and Southern blot analysis. The presence of the CP gene was assayed by PCR and Southern blot analysis, while the presence of the nptII gene was assayed by PCR only. Specific oligonucleotide primers to the 5 '-end and 3 '-end of the $\mathrm{CP}$ (forward 5'-atcattccatggtccaagaatgaagctgt-3' and reverse 5'-agctaaccatggggtgaaacagggtcg-3') and $n p t I I$ (forward 5'-cccctcggtatccaattagag-3' and reverse 5'-cggggggtgggcgaagaactccag-3') genes were used. A $2 \mu \mathrm{L}$ aliquot of $100 \mathrm{ng} \cdot \mu \mathrm{L}^{-1}$ solution of genomic DNA was used as template for PCR under the following conditions: $100 \mathrm{ng}$ of each dNTP, 1X PCR buffer, $100 \mathrm{ng}$ of each 5'-end and 3'-end primers, $1.5 \mathrm{~mm} \mathrm{MgCl}_{2}$, and 2.5 units of Taq DNA Polymerase per tube, in a $50 \mu \mathrm{L}$ volume. The program used to amplify the $\mathrm{CP}$ gene was one cycle of $94^{\circ} \mathrm{C}$ for $3 \mathrm{~min}$, followed by 30 cycles of $92{ }^{\circ} \mathrm{C}$ for $1 \mathrm{~min}, 53$ ${ }^{\circ} \mathrm{C}$ for $1 \mathrm{~min}$ and $72 \mathrm{C}$ for $2.5 \mathrm{~min}$, and one cycle of $72^{\circ} \mathrm{C}$ for $7 \mathrm{~min}$. The program used to amplify the $n p t I I$ gene was one cycle of $95^{\circ} \mathrm{C}$ for $5 \mathrm{~min}$, followed by 30 cycles of $92^{\circ} \mathrm{C}$ for $1 \mathrm{~min}, 55^{\circ} \mathrm{C}$ for $1 \mathrm{~min}$ and $72{ }^{\circ} \mathrm{C}$ for $1 \mathrm{~min}$, and one cycle of $72{ }^{\circ} \mathrm{C}$ for $7 \mathrm{~min}$. The PCR products were separated by $1 \%$ agarose gel electrophoresis (Sambrook et al., 1991). Aliquots of 5 to $15 \mu \mathrm{g}$ of genomic DNA were used for Southern blot analysis. Hind III-digested DNA was separated by $0.8 \%$ to $1 \%$ agarose gel electrophoresis (Sambrook et al., 1991). DNA was transferred to a GeneScreenPlus nylon membrane (BioTechnology Systems, NEN Research Products, Boston, Mont.) using capillary transfer as described in the manufacturer's protocol. The membrane was submitted to pre-hybridization, hybridization, washing, and autoradiography as described in Feinberg and Vogelstein (1983). A CP PCR fragment was used as a probe; amplification was done with primers to the $\mathrm{CP}$ gene that were previously described with the Agrobacteriumbinary vector pGA482GG/CPPRV-4 (Ling et al., 1991) as template. The ${ }^{32} \mathrm{P}$ labeling of the probe was done by a random primer-based system (Feinberg and Vogelstein, 1983).

ELISA analysis. Papaya leaves were homogenized in extraction buffer $(0.25 \mathrm{M}$ potassium phosphate, 0.1 м EDTA, pH 7.5) (Gonsalves and Ishii, 1980) and analyzed for total protein by the Bio-Rad Protein Assay (Bio-Rad Laboratories, N.Y.). The npt II gene expression (Cabanes-Bastos et al., 1989) in planta was detected by enzyme linked immunosorbent assay (ELISA) according to the manufacturer's conditions (5 Prime-3 Prime Inc., Boulder, Colo.). Homogenized leaf sample volumes of $100 \mu \mathrm{L}$ were used in these assays; the total protein content of which were adjusted to $100 \mu \mathrm{g}$. The absorbance was measured at 405 nm with a MicroELISA AutoReader MR700 (Dynatech Inc., Chantilly, Va.) 15 min after the addition of p-nitrophenyl phosphate (1 $\mathrm{mg} \cdot \mathrm{mL}^{-1}, 10 \%$ diethanolamine, $\mathrm{pH}$ 9.8). An average absorbance reading $\left(\mathrm{OD}_{405 \mathrm{~nm}}\right)$ of twice or greater the value observed for the negative control plants was regarded as positive. Double antibody sandwich ELISA(DAS-ELISA) was used to measure $\mathrm{CP}$ expression in tissue extracts containing 1.5 to $100 \mu \mathrm{g}$ of total protein as measured by the Bio-Rad Protein Assay (Bio-Rad Laboratories, N.Y.). Polyclonal and monoclonal antibodies produced against the PRSV HA 5-1 were used for coating and as a conjugate, respectively (Tennant et al., 1994).

\section{Results}

Line 63-1 contains two CP inserts that segregate independently. To understand the resistance of line 63-1, it was necessary to conclusively determine the number of segregating CP gene insertion sites. A population of $100 \mathrm{R}_{1}$ seedlings of line 63-1 was analyzed by PCR for the presence of the CP gene. Table 2 shows that 94 out of 100 seedlings were positive for the presence of the CP gene, giving an almost perfect 15:1 segregation ratio. Of these 100 plants, 50 were also examined for the presence of the nptII gene; all plants positive for the CP gene were also positive for $n p t I I$. Further analysis of the NPT II expression was done with these 50 plants. ELISA data revealed that all plants positive for CP and $n p t$ II genes were also positive for the expression of the NPT II protein (Table 2).

These results showed that line 63-1 has two insertion sites, and that the CP and npt II trans-

Table 2. Segregation analysis of the coat protein $(C P)$ and neomycin phosphotransferase II ( npt II $)$ transgenes by PCR and/or ELISA assay in populations derived from Sunset Solo line 63-1.

\begin{tabular}{|c|c|c|c|c|}
\hline \multirow[b]{2}{*}{ Population $^{z}$} & \multirow[b]{2}{*}{ Assay } & \multicolumn{2}{|c|}{ Ratio } & \multirow{2}{*}{$\begin{array}{c}\text { Chi square } \\
\qquad(P)^{\mathrm{x}}\end{array}$} \\
\hline & & Expected $^{y}$ & Observed & \\
\hline \multirow{3}{*}{$63-1 R_{1}$} & $C P-\mathrm{PCR}$ & $6.25 / 93.75$ & $6 / 94$ & $0.01(0.9-0.95)$ \\
\hline & $n p t I I-\mathrm{PCR}$ & $3.125 / 46.875$ & $4 / 46$ & $0.26(0.5-0.8)$ \\
\hline & NPT II-ELISA & $3.125 / 46.875$ & $4 / 46$ & $0.26(0.5-0.8)$ \\
\hline 63-1 R, A & $C P-\mathrm{PCR}$ & $\mathrm{ND}^{\mathrm{w}}$ & $0 / 50$ & ND \\
\hline $63-1 \mathrm{R}_{2}^{2} \mathrm{~B}$ & $C P-\mathrm{PCR}$ & ND & $0 / 50$ & ND \\
\hline $63-1 R_{3}^{2} E$ & $C P-\mathrm{PCR}$ & ND & $0 / 15$ & ND \\
\hline $63-1 R_{3}^{3} F$ & $C P-\mathrm{PCR}$ & ND & $0 / 13$ & ND \\
\hline
\end{tabular}

${ }^{\mathrm{z}} 63-1 \mathrm{R}_{1}$ (self-pollination of 63-1 $\mathrm{R}_{\mathrm{o}}$ plant); 63-1 $\mathrm{R}_{2} \mathrm{~A}\left(63-1 \mathrm{R}_{1}\right.$ plant $1268 \times$ Sunrise); 63-1 $\mathrm{R}_{2} \mathrm{~B}\left(63-1 \mathrm{R}_{1}\right.$ plant $1268 \times 63-1 \mathrm{R}_{1}$ plant 76); 63-1 $\mathrm{R}_{3} \mathrm{E}$ and $\mathrm{F}$ (self-pollination of PRSV-resistant 63-1 $\mathrm{R}_{2}$ plants, which had been obtained by self-pollinating $63-1 \mathrm{R}_{\mathrm{o}} \times 46-1 \mathrm{R}_{\mathrm{o}}$ hybrids also resistant to PRSV).

${ }^{y}$ Expected and observed ratio: number of negative plants per number of positive plants.

'Significant deviation from the expected ratio by chi-square test at $p<0.05$.

wot done.

genes were present at both sites. The observed 15:1 segregation ratio for the CP gene (Table 2 ), taken together with the amplification of a single fragment obtained in PCR using primers that anneal to the ends of this gene, showed that both insertion sites have at least one full length integrated $\mathrm{CP}$ gene. The data do not
show whether the CP genes at both sites are being expressed. However, it shows that both insertion sites have at least one inserted copy f the npt II gene that is being expressed. the $\mathrm{CP}$ gene, segregating independently, plant expression cassette containing the PRSV HA 5-1 CP gene, which was used to transform Sunset embryos and produce line $63-1$, is 2,036 nucleotides and has a HindIII site in profiles of HindIII -digested DNA of 63-1 R plants showed no signs of a two kb fragment. Instead, it showed that both sites of insertion lost at least one of the HindIII sites during the the restion 1A). Both HindIII -digested DNA fragments containing the $\mathrm{CP}$ gene were about 8 to $10 \mathrm{~kb}$. The fragments were difficult to separate by electrophoresis. However, in some cases both ands were visualized (Fig. 1B and C).

southern blot profile in Fig. 1B shows tion sites, while 10 has The profiles of 12 plants from population A suggested that plant 1268 is homozygous for the shorter CP gene containing-DNA fragment, and Alarger fragment (Fig. 1C) seven out of 12 showed the larger fragment. The insertion of the $\mathrm{CP}$ gene in the shorter DNA fragment (Fig. 1B) will be referred to as locus , and the larger fragment as locus L.

$C P$ inserts of both loci differentially affect the resistance conferred by 63-1 and resistance influenced by the challenge isolate. Given tion of 63-1, obtained by self-crossing 63-1 R plant, may consist of individuals with zero to four copies of the $\mathrm{CP}$ transgene insertion sites. effect of CP transgene copy to PRSV isolates, several experiments were designed. First, PRSV HA, PRSV BR, and PRSV TH were used to challenge the 63-1 
$\mathrm{R}_{1}$ population separately. These isolates were used because they elicit different resistance phenotypes on the varieties Rainbow and SunUp (that were derived from line 55-1). Both varieties are resistant to PRSV HA, only SunUp is resistant to PRSV BR, and both are susceptible to PRSV TH [although SunUp shows resistance when inoculated at an older age (Tennant et al., 2001)]. It was found that $36 \%$ of plants in the $63-1 R_{1}$ population were resistant to PRSVHA, while 34\% were resistant to PRSV BR, and 6\% were resistant to PRSV $\mathrm{TH}$ (Table 3). The results showed that the $\mathrm{S}$ and $\mathrm{L}$ loci are needed to confer resistance to any of the isolates.

In a second set of experiments, three $R_{2}$ populations were challenged by the three isolates to see whether the percentage of resistant plants increases from one generation to the other. These populations were derived from two plants that were resistant to the Brazilian isolate $\left(\mathrm{C}_{1}\right.$ and $\mathrm{C}_{2}$ ) and one resistant to the Thai isolate, were self-pollinated to produce $R_{2}$ populations $\left(D_{1}\right)$ (Table 1). Table 3 shows that plants of the $C_{1}$, $\mathrm{C}_{2}$, and $\mathrm{D}_{1} \mathrm{R}_{2}$ populations were $100 \%$ resistant to PRSV HA, while $87 \%$ of $\mathrm{C}$ plants and $93 \%$ of $\mathrm{C}_{2}$ plants were resistant to PRSV BR. In contrast, $93 \%$ of the plants in population $\mathrm{D}_{1}$ were susceptible to the Thai isolate. However, a range in severity of symptoms was seen among the plants. Some of the plants exhibited symptoms as severe as the nontransgenic control plants, while others developed very mild symptoms or were symptomless.

In a third set of experiments, two $R_{2}$
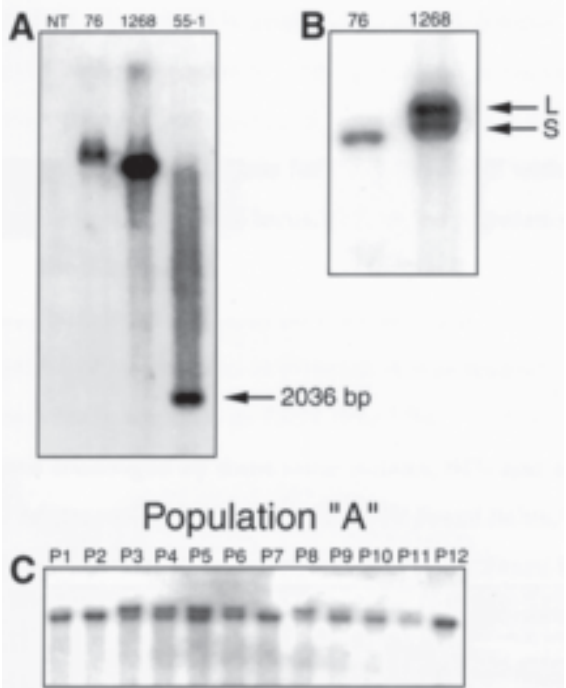

Fig. 1. Southern blot analysis of transgenic papaya plants of line 63-1 and 55-1. All samples shown were Hind III digested. (A) Nontransformed (NT), 63-1 R1 plant 76 (76), 63-1 $\mathrm{R}_{1}$ plant 1268 (1268), and SunUp papaya (55-1). SunUp shows a band with expected size of 2,036 bp, while 63-1 $\mathrm{R}$ plants show band(s) of 8 to $10 \mathrm{~kb}$ in size. (B) Plant 76 shows one restriction fragment containing the coat protein $(\mathrm{CP})$ sequence, while plant 1268 shows two restriction fragments. The fragments were assumed to represent the two insertion sites in line 63-1; the shorter one was designated the $\mathrm{S}$ locus, while the larger one the $\mathrm{L}$ locus. (C) $\mathrm{R}_{2}$ plants of population A of line 63-1 show segregation for locus $\mathrm{L}$, while locus $\mathrm{S}$ is present in all plants. populations, $\mathrm{A}$ and $\mathrm{B}$, were challenged with Hawaiian and Brazilian isolates. These populations were deliberately produced to decrease and increase, respectively, the percentage of plants with the same genotype as plant 1268 . Population A, generated from a cross between plant 1268 and a nontransformed plant, should contain plants with two different genotypes, SsLl (hemizygous for loci S and L) and Ssll (hemizygous for locus $\mathrm{S}$ and lacking locus L), in a 1:1 segregation ratio. No plant in this population would have the same genotype as plant 1268 for both CP loci; all would have fewer CP copies than the transgenic parental plant. Population B, on the other hand, was a result of a cross between 1268 and 76. Plant 76 has only the S locus, and it is not known whether it is in homozygous or hemizygous state. Only one out of 50 plants in population A was resistant to PRSV HA, while all plants were susceptible to PRSV BR. However, when population B was challenged by these same isolates, $84 \%$ and $44 \%$ of the plants showed resistance to PRSV HA and PRSV BR, respectively (Table 3 ).

The last set of experiments was designed to evaluate the effect of CP gene copy number on the spectrum of resistance to PRSV isolates. Two $63-1 \mathrm{R}_{3}$ populations, $\mathrm{E}$ and $\mathrm{F}$, developed by recurrent selection under greenhouse and field conditions in Hawaii (Table 1), were challenged separately by PRSV HA, PRSVBR, and PRSV TH. Both populations showed 100\% of resistance to the Hawaiian and Brazilian isolates, and about $65 \%$ of the plants showed resistance to the Thai isolate. Some of these plants resistant to the Thai isolate were chal-

Table 3. Response of $\mathrm{R}_{1}, \mathrm{R}_{2}$, and $\mathrm{R}_{3}$ populations of line 63-1 to challenge by mechanical inoculation of PRSV HA, PRSV BR, or PRSV TH.

\begin{tabular}{|c|c|c|}
\hline Population ${ }^{z}$ & PRSV isolate & Response $^{y}$ \\
\hline \multirow{3}{*}{$63-1 R_{1}$} & $\mathrm{BR}$ & $17 / 50(34 \%)$ \\
\hline & $\mathrm{HA}$ & $18 / 50(36 \%)$ \\
\hline & $\mathrm{TH}$ & $3 / 50(6 \%)$ \\
\hline \multirow{2}{*}{$63-1 \mathrm{R}_{2} \mathrm{C}_{1}$} & BR & $26 / 30(87 \%)$ \\
\hline & HA & $30 / 30(100 \%)$ \\
\hline \multirow{3}{*}{ 63-1 $\mathrm{R}_{2} \mathrm{C}_{2}$} & BR & $28 / 30(93 \%)$ \\
\hline & HA & $30 / 30(100 \%)$ \\
\hline & $\mathrm{TH}$ & $0 / 30(0 \%)$ \\
\hline \multirow{2}{*}{ 63-1 R $\mathrm{D}_{1}$} & $\mathrm{TH}$ & $2 / 30(7 \%)$ \\
\hline & $\mathrm{HA}$ & $30 / 30(100 \%)$ \\
\hline \multirow{2}{*}{$63-1 R_{2} A$} & BR & $0 / 50(0 \%)$ \\
\hline & $\mathrm{HA}$ & $1 / 50(2 \%)$ \\
\hline \multirow[t]{2}{*}{$63-1 R_{2} B$} & BR & $22 / 50(44 \%)$ \\
\hline & $\mathrm{HA}$ & $42 / 50(84 \%)$ \\
\hline \multirow{3}{*}{$63-1 R_{3} E$} & BR & $11 / 11(100 \%)$ \\
\hline & $\mathrm{HA}$ & $11 / 11(100 \%)$ \\
\hline & $\mathrm{TH}$ & $10 / 15(67 \%)$ \\
\hline \multirow[t]{3}{*}{$63-1 R_{3} F$} & $\mathrm{BR}$ & $11 / 11(100 \%)$ \\
\hline & HA & $10 / 10(100 \%)$ \\
\hline & $\mathrm{TH}$ & $10 / 16(63 \%)$ \\
\hline
\end{tabular}

${ }^{\mathrm{z}} 63-1 \mathrm{R}_{1}$ (self-pollination of 63-1 R plant); 63-1 R $C_{1}$ (self-pollination of 63-1 $R_{1}$ plant P17); 63-1 $R_{2}$ $\mathrm{C}_{2}$ (self-pollination of 63-1 $\mathrm{R}_{1}$ plant P07); 63-1 $\mathrm{R}_{2}$ $\mathrm{D}_{1}$ (self-pollination of 63-1 $\mathrm{R}_{1}$ plant P88); 63-1 $\mathrm{R}_{2}$ A (63-1 R plant $1268 \times$ Sunrise); 63-1 R B (63-1 $\mathrm{R}_{1}$ plant $1268 \times 63-1 \mathrm{R}_{1}$ plant 76$) ; 63-1 \mathrm{R}_{3} \mathrm{E}$ and $\mathrm{F}$ (self-pollination of PRSV-resistant 63-1 R plants, which had been obtained by self-pollinating 63-1 R $\times 46-1 \mathrm{R}$ hybrids also resistant to PRSV.).

y Data shown as number of resistant plants per number of plants challenged, and as percentage of resistant plants (in parenthesis). lenged for a third time with this isolate, and they all exhibited sustained resistance. These results showed that a recurrent selection program based on greenhouse and field resistance resulted in the increase in the number of plants resistant to either homologous or heterologous PRSV isolates. Although 63-1 line has been crossed to 46-1 line, early in the selection, it is important to remember that line $46-1$ is negative for the CP transgene. Thus, plants from populations $\mathrm{E}$ and $\mathrm{F}$ would only have loci $\mathrm{S}$ and $\mathrm{L}$ in their genotypes. No other $\mathrm{CP}$ transgene, besides the ones in loci $\mathrm{S}$ and $\mathrm{L}$, would be contributing to increase gene dosage in these two populations.

Resistance to PRSV BR is not correlated to coat protein expression. An attempt was made to correlate the level of CP expression, measured by DAS-ELISA, with the response to virus inoculation. First, ten 63-1 $\mathrm{R}_{1}$ plants were randomly selected from the population challenged by the Brazilian isolate; five being resistant and five susceptible. The $\mathrm{CP}$ accumulation in these plants, measured by DASELISA, revealed that four of the five resistant plants had a low amount of CP, while four of five susceptible plants had an amount of CP about four times higher than the resistant plants (Fig. 2). These results suggested a link between resistance and low $\mathrm{CP}$ gene expression and a RNA-mediated protection system.

In order to evaluate this possibility further, $\mathrm{CP}$ gene expression in populations A and $\mathrm{B}$ was investigated. It was hypothesized that by looking at these two populations, plants with low and high levels of CP could be found. A correlation between the levels of CP in these plants and their response to virus challenge would give an indication to whether the engineered resistance in line 63-1 is a case of PTGS or not. Two new sets of plants from population A and B were produced, each containing 23 plants. The CP level in each plant was measured by DAS-ELISA. Both populations did not show a distinct separation between the two expected levels of CP expression. Instead, they showed a continuous range of CP expression, where the highest reading was about three times higher than the lowest readings. Besides that, the lowest readings in population A were in the same range as the lowest readings in population $\mathrm{B}$; the same was true for the highest readings. Two plants with relative low and two with relative high readings were selected in each population for analysis by challenge inoculation with PRSV BR. All four plants from population A plus two plants from population B (one with low and one with high reading) were susceptible, while two plants from population B (one with low and one with high reading) were resistant to this PRSV isolate. These results suggest a complete lack of correlation between the levels of CP (by DAS-ELISA) and the phenotype resulting from the challenge by PRSV.

\section{Discussion}

Recently, line 63-1 (Fitch et al., 1992) was presented as an alternative transgenic line to combat PRSV in Hawaii and elsewhere (Ten- 
nant et al., 2005). Line 63-1, unlike line 55-1 and its derivatives, not only shows resistance to nonHawaiian PRSV isolates, but previous studies point to more than one segregating CP gene locus (Tennant et al., 2005). On this basis, line 63-1 is a useful model to study the relationship between $\mathrm{CP}$ gene copy number and spectrum of resistance.

The present study has confirmed that line 63-1 has two CP gene integration sites, and that they segregate independently. Both sites of integration show the presence of the CP and $n p t I I$ genes. Consequently, any population generated by self-crossing the hermaphrodite $\mathrm{R}_{0}$ 63-1 plant will contain plants carrying from zero to four copies of these genes. Considering the expression of the $\mathrm{CP}$ gene, and assuming that both loci ( $\mathrm{S}$ and $\mathrm{L}$ ) are expressing this gene at different rates, up to nine different $\mathrm{CP}$

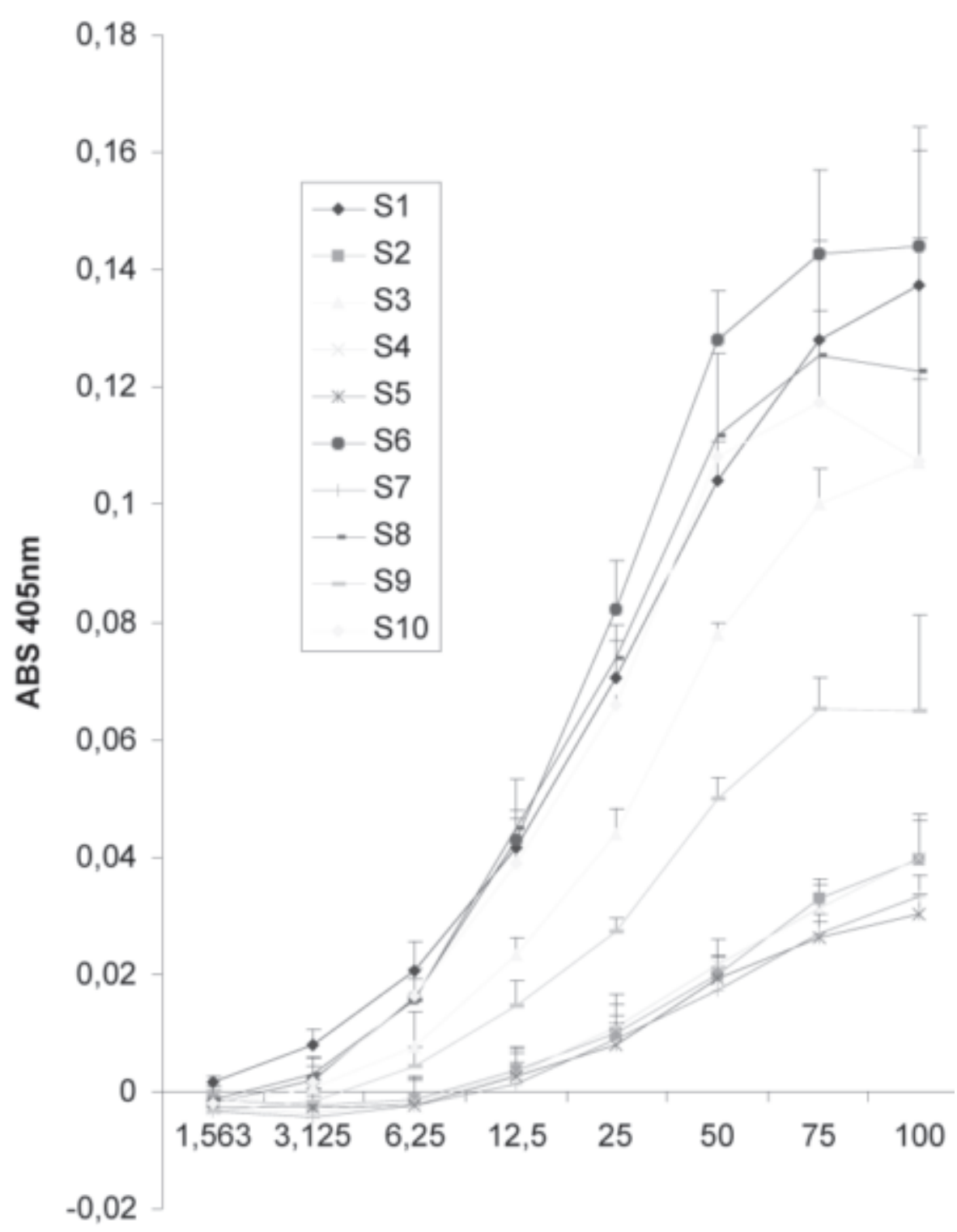

Total Protein $\mu \mathrm{g}$ )

Fig. 2. Coat protein accumulation in $63-1 \mathrm{R}_{1}$ plants. $\mathrm{S}_{1}, \mathrm{~S}_{6}, \mathrm{~S}_{8}, \mathrm{~S}_{9}$, and $\mathrm{S}_{10}$ were susceptible, while $\mathrm{S}_{2}, \mathrm{~S}_{3}$, $\mathrm{S}_{4}, \mathrm{~S}_{5}$, and $\mathrm{S}_{7}$ were resistant to PRSV BR. Plants were assayed by DAS-ELISA using monoclonal antibodies against PRSV HA 5-1. Plates were read at OD $405 \mathrm{~nm} 60 \mathrm{~min}$ after the addition of substrate. Measurements were done at $1.56,3.13,6.25,12.5,25,50,75$, and $100 \mu \mathrm{g}$ of total protein. Data are shown as average of three readings. Standard error bars are also shown.

expression levels could be found in the 63-1 $\mathrm{R}_{1}$ population.

The strategy used to assess the effect of transgene copy number was based in the segregation of the phenotypes resistance and susceptibility to PRSV. As seen in Tennant et al. (2005), and in the present study, the 63-1 $R_{1}$ population shows resistance to all three PRSV isolates tested. A consistent gain in resistance to the homologous PRSV HA and to the heterologous PRSV BR was seen as gene dosage increases in self-pollinated or sib-mated $R_{2}$ and $R_{3}$ populations generated from plants resistant to PRSV HA. The same was true when the selection was performed with PRSV BR.

Based on the results of this study, it can be hypothesized that plants derived from line 63-1
must have the CP transgene $\mathrm{S}$ in homozygous state or the $\mathrm{CP}$ transgene $\mathrm{L}$ in homozygous state to be resistant to PRSV HA. On the other hand, plants resistant to PRSV BR must have the $\mathrm{CP}$ transgene $\mathrm{S}$ in hemizygous state and the $\mathrm{CP}$ transgene $\mathrm{L}$ in homozygous state. Assuming this hypothesis true, then $44 \%$ of the plants from the 63-1 $\mathrm{R}_{1}$ population (self of the 63-1 $\mathrm{R}_{0}$ plant) should be resistant to PRSV HA (36\% turned out to be resistant); and $38 \%$ of the plants from this same population should be resistant to PRSV BR (34\% turned out to be resistant). The results of the challenge of population 63-1 $\mathrm{R}_{2}$ A do not disagree with the hypothesis, while results of the challenge of population 63-1 $R_{2}$ B disagree with it, independent of 63-1 $\mathrm{R}_{1}$ plant 76 genotype. In the case of populations $\mathrm{C}_{1}$ and $\mathrm{C}_{2}$, if 63-1 $\mathrm{R}_{1}$ plant 07 and 17 were both SsLL, the results are explained by the hypothesis.

Despite the high percentage of plants resistant to the Thai isolate seen in 63-1-derived populations, such as $\mathrm{R}_{3}$ populations $\mathrm{E}$ and $\mathrm{F}$, no gain in resistance to this isolate was seen in $R_{2}$ populations $C_{2}$ and $D_{1}$. Some of the plants in these last two populations showed much less severe symptoms than the ones seen in the nontransformed control plants. This decrease in symptoms severity could be considered partial resistance, somewhere between the apparent immunity seen in the resistant plant and the type of response seen in a nontransformed plant. A partially resistant plant would show symptoms, however these would be much milder than the ones seen in a nontransformed plant, as if the plant would be able to somehow battle the virus, decreasing the effects of its presence, but not able to prevent its systemic establishment. It is important to state that plants showing the suggested partial resistance phenotype were considered susceptible for the sake of this work; only plants apparently immune to the virus 3 weeks after two mechanical inoculations were considered resistant. The phenotype seen in PRSV resistant 63-1 plants were similar to those observed for PRSV resistant 55-1 plants.

The presence of the CP transgene in the genome of plants derived from line 63-1 does not assure resistance even for the homozygous isolate. In contrast to line 55-1 (Tennant et al., 1994), line 63-1 does not appear to be resistant to the homologous isolate (PRSV HA) when both loci are in hemizygous state. Furthermore, an apparent higher number of copies seem to be necessary to obtain resistance against heterologous isolates. The fact that the percentage of plants resistant to either the Hawaiian and the Brazilian isolates increases considerably from population A to B points to the importance of $\mathrm{CP}$ transgene copy number in the resistance to PRSV seen in line 63-1.

The strengthening of the resistance phenotype and/or the broadening of the spectrum of resistance, as a consequence of increments in the number of transgene copies (and consequently the gene dosage), is a phenomenon already described. McDonald et al. (1997) observed this phenomenon in transgenic tobacco plants carrying the $\mathrm{CP}$ gene from the $\mathrm{N}$ strain of potato Y virus (PVY) and tested against the homologous and some heterologous strains 
of PVY. In that report, a lower resistance was also seen against some heterologous strains, resembling the partial resistance to the Thai isolate described in this report. Goodwin et al. (1996) observed that a minimal transgene copy number was necessary to establish a highly resistant state in a tobacco line expressing multiple copies of an untranslatable tobacco etch virus (TEV) CP gene. When CP transgene copies below the minimum were present, an inducible form of resistance was seen instead of a highly resistant state (Goodwin et al., 1996). No recovery phenotype was seen in the present study with line 63-1.

Increase in gene dosage, resulting in the strengthening of the resistance phenotype not only against the homologous PRSV isolate but also the heterologous ones, can be achieved by pyramiding transcriptionally active $\mathrm{CP}$ transgenes in the genome of a papaya plant. This transgene management through recurrent selection has the potential to generate a transgenic papaya variety highly resistant to many PRSV isolates. Potentially, even CP transgenes of plants that do not show resistance to PRSV could be used to achieve the gene dosage necessary for a state of wide spectrum of high resistance. Mueller et al. (1995) observed the positive effect of such kind of transgene when crossing transgenic tobacco plants expressing the RNA polymerase gene from PVX.

It is likely that there is a level of nucleotide sequence divergence in the $\mathrm{CP}$ gene of PRSV isolates where no matter how much the gene dosage is increased, no change from susceptible to resistant phenotype will be accomplished. English and Baulcombe (1997) observed changes in transgene transcription resulting from epigenetic variation caused by a simple tissue culture/regeneration scheme. These changes resulted in loss of the resistance phenotype and were associated with decrease in transcription due to promoter methylation. It is known that a transgene can trans-inactivate another with homology in the promoter region (Neuhuber et al., 1994), resulting in transcriptional gene silencing (TGS). It would be interesting to see if the quantitative factor (transgene copy number) can reach a point where qualitative effects can be affected, resulting in lost of the resistance.
In conclusion, the results presented here have shown that transgene copy number is a major factor in the PRSV: transgenic papaya resistance system found in line 63-1. The spectrum of resistance in this line increases as the $\mathrm{CP}$ transgene copy number increases in the plant's genome. A similar response to the enrichment on the number of transgene copy was seen in line 55-1 and its derivates (Tennant et al., 2001). No correlation was found between the levels of CP expression and the resistance to PRSV BR in line 63-1.

\section{Literature Cited}

Cabanes-Bastos, E., A. Day, and C. Lichtenstein. 1989. A sensitive and simple assay for neomycin phosphotransferase II activity in transgenic tissue. Genetics 77:169-176.

English, J.J. and D.C. Baulcombe. 1997. The influence of small changes in transgene transcription on homology-dependent virus resistance and gene silencing. Plant J. 12(6):1311-1218.

Feinberg, A. and B. Vogelstein. 1983. A technique for radiolabelling DNA restriction endonuclease fragments to high specific activity. Anal. Biochem. 132:6-13.

Ferreira, S., K. Pitz, R. Manshardt, F. Zee, M. Fitch, and D. Gonsalves. 2002. Virus coat protein transgenic papaya provides practical control of papaya ringspot virus in Hawaii. Plant Dis. 86:101-105.

Fitch, M., R. Manshardt, D. Gonsalves, J. Slightom, and J. Sanford.1992. Virus resistant papaya plants derived from tissues bombarded with the coat protein gene of papaya ringspot virus. Bio/Technology 10:1466-1472.

Gonsalves, D. 1998. Control of papaya ringspot virus in papaya: Acase study. Annu. Rev. Phytopathol. 36:415-437.

Gonsalves, D. and I. Ishii. 1980. Purification and serology of papaya ringspot virus. Phytopathology 70:1028-32.

Goodwin, J., K. Chapman, S. Swaney, T.D. Parks, E.A. Wernsman, and W.G. Dougherty. 1996. Genetic and biochemical dissection of transgenic RNA-mediated virus resistance. Plant Cell 8(1):95-105.

Ling, K.S., S. Namba, C. Gonsalves, J. Slightom, and D. Gonsalves. 1991. Protection against detrimental effects of potyvirus infection in transgenic tobacco plants expressing the papaya ringspot virus coat protein gene. Bio/Technology 9:752-758.
Lius, S. 1994. Characterization and evaluation of papayas genetically transformed with the coat protein gene of papaya ringspot virus. MS thesis. Univ. Hawaii, Honolulu.

Lius, S., R.M. Manshardt, M. Fitch, J.L. Slightom, J.C. Sanford, and D. Gonsalves. 1997. Pathogenderived resistance provides papaya with effective protection against papaya ringspot virus. Mol. Breed. 3(3):161-168.

Manshardt, R.M. 1998. 'UH Rainbow' papaya. Univ. Hawaii College Trop. Agr. Human Resour. Germplasm G-1.

McDonald, J.G., J.E. Brandle, S. Gleddie, J.A. Hermans, and I.R. Kermali. 1997. Resistance to homologous and heterologous strains of potato virus $\mathrm{Y}$ in transgenic tobacco carrying the PVYN coat protein gene. Can. J. Plant Sci. 77:167-171.

Mueller, E., J. Gilbert, G. Davenport, G. Brigneti, and D.C. Baulcombe. 1995. Homology-dependent resistance: transgenic virus resistance in plants related to homology-dependent gene silencing. Plant J. 7(6):1001-1013.

Neuhuber, F., Y.D. Park, A.J.M. Matzke, and M.A. Matzke. 1994. Susceptibility of transgene loci to homology-dependent gene silencing. Mol. Gen. Genet. 244:230-241.

Sambrook, J., E. Fritsch, and T. Maniatis. 1991. Molecular cloning: A laboratory manual. Cold Spring Harbour Laboratory, Cold Spring Harbour, N.Y.

Souza, Jr., M.T. and D. Gonsalves. 2005. Sequence similarity between the viral $c p$ gene and the transgene in transgenic papayas. Braz. J. Agr. Res. 40(5):479-486.

Tennant, P.F., G. Fermin, M. Fitch, R. Manshardt, J. Slightom, and D. Gonsalves. 2001. Papaya rinsgpot virus resistance of transgenic Rainbow and SunUp is affected by gene dosage, plant development, and coat protein homology, Euro. J. Plant Pathol. 107:645-653.

Tennant, P.F., M.T. Souza, Jr., M. Fitch, R. Manshardt, J.L. Slightom, and D. Gonsalves.2005. Line 63-1, a new virus-resistant transgenic papaya for Hawaii. HortScience (in press).

Tennant, P.F., C. Gonsalves, K.S. Ling, M. Fitch, R. Manshardt, J.L. Slightom, and D. Gonsalves. 1994. Differential protection against papaya ringspot virus isolates in coat protein gene transgenic papaya and classically cross-protected papaya. Phytopathology 84(11):1359-1366.

Yeh, S.D. and D. Gonsalves. 1984. Evaluation of induced mutants of papaya ringspot virus for control by cross protection. Phytopathology 74:1086-1091. 